\title{
CHARACTERISTICS OF TRUE LAKE BREEZES ALONG THE EASTERN SHORE OF LAKE MICHIGAN
}

\author{
EDWARD RYZNAR* \\ Department of Atmospheric and Oceanic Science University of Michigan Ann Arbor, MI, 48109, U.S.A.
}

and

JAWAD S. Touma

Consumers Power Company Jackson, MI 48201, U.S.A.

(First received 30 June 1980 and in final form 17 November 1980)

\begin{abstract}
Abatract-Measurements of temperature, humidity and wind velocity made from 1973 to 1978 at several special stations near Lake Michigan are analyzed to determine true lake breeze oocurrences, movement inland and effects of cloudiness and wind speed on lake breeze behavior. A total of 187 true lake breezes occurred in the 6 year period, with July and August having the most frequent occurrences. Nearly half of these moved inland as far as $19 \mathrm{~km}$. Fifty retreated lakeward after having moved inland. The formation and behavior of true lake breezes are discussed in relation to the strength of the offshore wind and cloudiness. Vertical temperature differences associated with the passage, duration and retreat of true lake breezes are presented and discussed.
\end{abstract}

\section{INTRODUCTION}

Lake and land breeze circulations play a key role in determining not only average temperatures in the coastal zone of Lake Michigan in the spring and summer months but also atmospheric diffusion and transport processes taking place there. The rapid shift in wind direction from offshore to onshore, the decrease in temperature and the increase in humidity near the ground caused by the passage of a true lake breeze front, for example, are also accompanied by changes in thermal stability and turbulence characteristics. These changes may affect diffusion conditions in a layer several hundred meters thick.

As discussed in detail by Wexler (1946) and by others, a lake breeze is a thermally induced daytime onshore wind resulting from the land becoming warmer than the water. As opposed to lake breezes which form when the average wind direction is already onshore, a true lake breeze, as defined here, is air that is moving onshore and inland from Lake Michigan and displacing warmer air that is moving lakeward. It is abbreviated here as TLB.

The offshore wind preceding the TLB is caused by the large-scale pressure distribution. For the Lake Michigan region, a high pressure area centered northeast of the lake often produces offshore winds and cloudless skies along the eastern shoreline and leads to TLB formation in the warm seasons. For this condition, Weber (1978) showed hodographically that if a TLB forms, the general behavior of wind direction throughout the day near the eastern shoreline consists of a morning shift from easterly to westerly, a gradual veering to more northerly through the day due to the
Coriolis effect and a gradual evening shift to easterly.

If a horizontal pressure distribution is such that it is causing an onshore wind when a lake breeze forms, the lake breeze manifests itself mainly by enhancing the onshore wind speed. For this condition, changes in wind direction, temperature and humidity are less than those caused by the TLB. An additional difference is that a typical variation of wind direction with height associated with a fully developed TLB consists of onshore winds up to about $500 \mathrm{~m}$, above which there is a thicker layer of air moving offshore at a slower speed (Moroz, 1967). In the case of an enhancement of an existing onshore wind by a lake breeze, however, there is no offshore wind, or return flow. Many intermediate flow patterns unique to shoreline conditions exist between the TLB and the enhancement cases.

Mesoscale wind analyses of lake breeze circulations for the western shore of Lake Michigan have been described in Keen and Lyons (1978) and in Keen et al., (1979) in relation to lake breeze effects on the diffusion of aerosols near a shoreline. The latter work contains a detailed analysis of a lake breeze which the authors regarded as having textbook characteristics. It occured on 4 September 1974 and had many of the meteorological characteristics of the true lake breezes discussed in the present paper. As a result of other meteorological similarities, the diffusion conditions which were found to be associated with this lake breeze are probably similar to those caused by true lake breezes discussed here. In addition, many characteristics of vertical variations of wind direction found by Moroz (1967) in a case study of a true lake breeze near Muskegon, MI, are also likely to be similar to those associated with true lake breezes discussed in this paper. 


\section{INSTRUMENTATION AND MEASUREMENTS}

Data for the lake breeze study were obtained during a study of meteorological effects of mechanical-draft cooling towers at the Palisades Nuclear Plant near South Haven, Michigan, and of a once-through cooling system at the Donald C. Cook Nuclear Plant near Benton Harbor, Michigan. Both plants are located on the Lake Michigan shoreline in southwest Lower Michigan. Their locations are shown in Fig. 1 along with locations of a special 25 station meteorological network which was installed for the study in 1972-1973. As described in Ryznar, et al. (1976), each station was equipped with a hygrothermograph and a recording precipitation guage. The principal stations, denoted by numbers 3 and 7 in the Palisades network and by 3 and 10 in the Cook network had, in addition, equipment for recording visibility, wind speed and direction and solar irradiance.
Data on the vertical distributions of wind and temperature were obtained from meteorological towers located on both plant sites. On the Cook tower, temperature was measured at heights of 9 and $55 \mathrm{~m}$ and wind velocity was measured at heights of 15 and $45 \mathrm{~m}$. These data were made available in the form of hourly averages for the years 1975 to 1978 by Meteorological Evaluation Services Inc., Amityville, N.Y. On the Palisades tower located about $30 \mathrm{~km}$ north of the Cook site, temperature, wind velocity and wind direction fluctuations were measured at 10 and $60 \mathrm{~m}$ since December 1977, when a new meteorological tower and data acquisition system were put into operation. Both towers are located on wooded sand dunes about $40 \mathrm{~m}$ above the level of Lake Michigan and about $0.8 \mathrm{~km}$ inland. Because of these geographical similarities and the proximity of the towers to each other, similarities in average meteorological data from each could be expected.

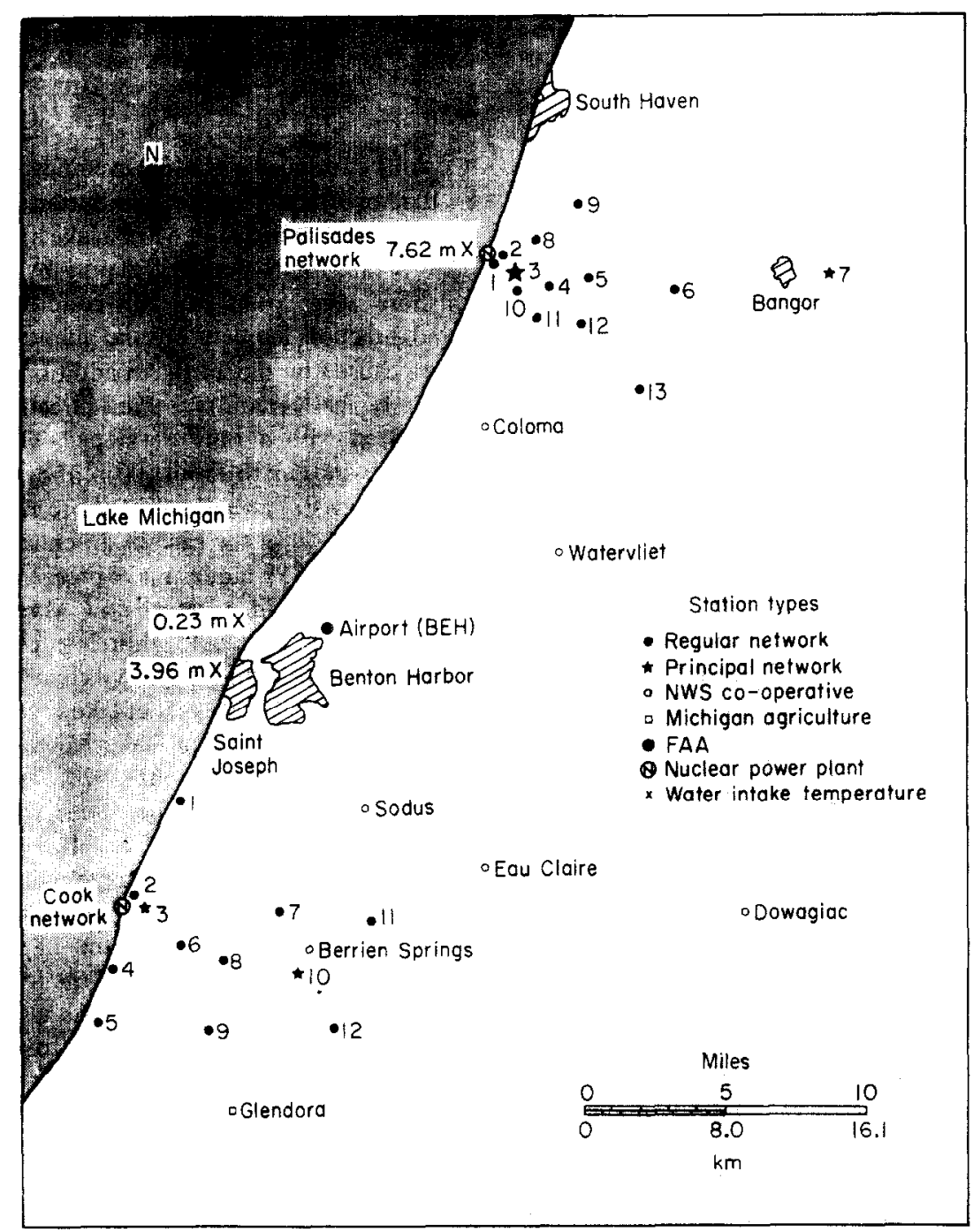

Fig. 1. Locations of special meteorological stations in the Palisades and Cook networks and other stations in southwest Lower Michigan. 


\section{METHOD OF ANALYSIS}

A requirement in determining each TLB occurrence was to establish that the measured changes in meteorological variables were produced only by the TLB. For example, the rapid temperature decrease and humidity increase caused by a TLB frontal passage can also be caused by a large cumulus cloud shading the sun on a warm day. Unlike the TLB, however, cloud-induced changes are not accompanied by a wind shift from offshore to onshore as they are with a TLB. Because a cold front moving inland usually does cause all of the changes caused by a TLB, weather maps were examined to determine if the pressure distribution was conducive to producing an offshore gradient wind and to exclude days with cold frontal passages.

In addition, because TLB formation and behavior are highly dependent on wind speed and cloudiness, daytime hourly weather observations made at the Federal Aviation Administration Office at Benton Harbor, MI, were examined to determine cloudiness and wind characteristics for each day. If a day was either cloudless or partly cloudy with an offshore gradient wind, a TLB was likely to form. For each of these days, recordings of wind direction, temperature and humidity for each station were inspected for rapid changes which gradually progressed inland. The period of recordings examined included all daytime periods between March and November from 1973 to 1978 .

In general, it was found that a TLB occurred near the shoreline between 09.00 and 11.00 local time if the sky was cloudless, or nearly so, and if the offshore wind speed did not exceed about $5 \mathrm{~m} \mathrm{~s}^{-1}$. As it passed stations within about $1 \mathrm{~km}$ of the shoreline the TLB caused a decrease in temperature of about $2^{\circ} \mathrm{C}$ and an increase in relative humidity of at least $15 \%$ within a $15 \mathrm{~min}$ period. Vigorous mixing in the TLB frontal zone caused the changes to become less farther inland. The magnitudes and times of these changes at each station were tabulated so that occurrences, penetrations inland and general behavior of the TLB as affected by other meteorological variables could be determined.

\section{OCCURRENCES}

The number of TLB occurrences for each month between March and November for each year between 1973 and 1978 is shown in Table 1.

Table 1 shows that an average of about 31 TLB occur between March and November of each year and that July and August have the largest number of occurrences.

The frequent TLB occurrences in these two months can be explained in terms of average air and water temperatures, cloudiness and wind speeds which occur in combination along the eastern shore of Lake Michigan. Compared to average conditions for the other months shown, July and August have the highest
Table 1. Monthly occurrences of true lake breezes for 1973 to 1978

\begin{tabular}{rrrrrrrrrrr}
\hline & M & A & M & J & J & A & S & O & N & Total \\
\hline 1973 & 5 & 3 & 2 & 2 & 2 & 3 & 1 & 3 & 0 & 21 \\
1974 & 3 & 1 & 4 & 5 & 7 & 10 & 5 & 0 & 0 & 35 \\
1975 & 1 & 3 & 4 & 4 & 5 & 7 & 3 & 1 & 2 & 30 \\
1976 & 2 & 2 & 5 & 4 & 4 & 8 & 4 & 1 & 0 & 30 \\
1977 & 1 & 6 & 6 & 6 & 4 & 5 & 3 & 2 & 0 & 33 \\
1978 & 0 & 6 & 7 & 3 & 7 & 9 & 5 & 0 & 1 & 38 \\
Total & 12 & 21 & 28 & 24 & 29 & 42 & 21 & 7 & 3 & 187 \\
\hline
\end{tabular}

maximum temperatures (about $26^{\circ} \mathrm{C}$ ), the least daytime cloudiness (about 4/10 coverage) and the lowest wind speeds (about $4 \mathrm{~m} \mathrm{~s}^{-1}$ ). The average water temperature near the surface is about $21^{\circ} \mathrm{C}$. The overall result of these conditions is that the land to water temperature difference, which is the driving force of the TLB, is enhanced in these months by: (1) the small amount of daytime cloudiness, which allows the land to warm; and (2) by the low wind speeds, which remove proportionately less heat from the land by turbulent exchange than do the higher wind speeds of the other months shown.

\section{PENETRATION INLAND}

Table 2 shows the 187 occurrences in terms of the number that reached various maximum distances inland.

Table 2. Number of true lake breezes reaching maximum distances inland

\begin{tabular}{lrrrrrr}
\hline & $\leqslant 1 \mathrm{~km}$ & $1-5 \mathrm{~km}$ & $5-11 \mathrm{~km}$ & $11-19 \mathrm{~km}$ & $>19 \mathrm{~km}$ \\
\hline 1973 & 4 & 2 & 4 & 3 & 8 \\
1974 & 3 & 3 & 6 & 10 & 13 \\
1975 & 2 & 7 & 7 & 5 & 9 \\
1976 & 1 & 3 & 7 & 7 & 12 \\
1977 & 2 & 1 & 10 & 5 & 15 \\
1978 & 3 & 6 & 5 & 5 & 19 \\
Total & 15 & 22 & 39 & 35 & 76 \\
\hline
\end{tabular}

A total of 76 of the 187 TLB, or nearly half, moved at least as far inland as the $19 \mathrm{~km}$ station. On the other hand, 15 passed the shoreline stations but were just barely discernible when they passed those stations near $1 \mathrm{~km}$.

Although they are not shown in Table 2, 50 TLB moved some distance inland but then retreated lakeward. This was caused either by an increase in offshore wind speed or by an increase in cloudiness. In some cases, both occurred. Of the 50 TLB which returned lakeward, 24 returned as far as the shoreline itself. These occurrences were detectable as the lakeward movement of a zone with an increase in temperature, a decrease in humidity and a wind shift from onshore to offshore. In some cases the retreat 
was traceable to within a certain distance of the lake but then became unidentifiable as a discontinuity due to natural cooling of the land surface in the late afternoon.

In terms of cloudiness and wind speed effects on TLB formation and movement inland, it was found that:

(1) A TLB formed if the sky was cloudless (or nearly so) and if the speed of the existing wind blowing lakeward did not exceed about $5 \mathrm{~ms}^{-1}$. It usually formed between 09.00 and 11.00 local time and moved inland at a speed of about $1-2 \mathrm{~m} \mathrm{~s}^{-1}$. The lighter the offshore wind and the fewer the clouds, the earlier it formed and the faster and farther it moved inland.

(2) If the sky was cloudless and the offshore wind speed was as high as $6 \mathrm{~m} \mathrm{~s}^{-1}$, a TLB was likely to form, but not until later in the day, usually near the time of maximum temperature difference between lake and land. Also, it was not likely to penetrate more than $5 \mathrm{~km}$ inland, with a strong possibility that it would be forced to retreat lakeward.

(3) A TLB did not form if the offshore wind speed was as high as $7 \mathrm{~m} \mathrm{~s}^{-1}$ even if the sky was cloudless. Also, if more than $7 / 10$ of the sky was covered by opaque cloudiness, a TLB did not form even in nearly calm winds.

\section{VERTICAL TEMPERATURE STRUCTURE}

The availability of temperature measurements for the Cook and Palisades meteorological towers enabled TLB effects on thermal stability to be determined. Hourly averages of temperature differences between 9 and $55 \mathrm{~m}$ (denoted here as $T_{55}-T_{9}$ ), for the Cook tower were compiled for the 131 TLB cases from 1975 to 1978. Similar data for the $10 \mathrm{~m}$ and $60 \mathrm{~m}$ heights of the Palisades tower were compiled for the 38 TLB cases in 1978. The effects of wind shifts and average offshore and onshore wind directions associated with the TLB were determined using hourly values: (1) for the hour prior to TLB passage; (2) before and after TLB passage; (3) for the period of onshore wind; (4) before and after the evening wind shift from onshore to offshore; and (5) for the hour after evening wind shift.

The results using temperature differences measured on the Cook meteorological tower only are shown in Tables 3 and 4 . Table 3 gives hourly averages of
Table 3. Average values of $T_{s s}-T_{9}$ for true lake breezes for the Cook meteorological tower*

\begin{tabular}{lrrrrrrr}
\hline Sign & \multicolumn{9}{c}{ Hour prior } & \multicolumn{2}{c}{$\begin{array}{c}\text { During } \\
\text { onshore winds }\end{array}$} & \multicolumn{2}{c}{ Hour after } \\
\hline & Cases & ${ }^{\circ} \mathrm{C}$ & Cases & ${ }^{\circ} \mathrm{C}$ & Cases & ${ }^{\circ} \mathrm{C}$ \\
Neg. & 116 & -0.8 & 116 & -0.7 & 45 & -0.5 \\
Pos. & 5 & +1.6 & 6 & +0.5 & 65 & +0.8 \\
Zero & 4 & 0 & 1 & 0 & 12 & 0 \\
\hline
\end{tabular}

* Differences in the total number of cases in the categories are caused by missing data.

temperature differences for the hour before TLB passage, during the period with onshore winds and for the hour after the evening wind shift from onshore to offshore.

Table 3 shows that a negative temperature dif. ference was most common for both the hour prior to TLB passage and for the duration of onshore winds. Converting the actual temperature difference, $T_{55}-T_{9}=-0.8^{\circ} \mathrm{C}$, into potential temperature difference for the same height interval gives a value of about $-0.3^{\circ} \mathrm{C}$. If vertical consistency in the temperature profile is assumed, this is equivalent to a decrease in potential temperature with height of about $-0.7 \mathrm{C} / 100 \mathrm{~m}$ or slightly less than the adiabatic lapse rate. For the hour after the evening wind shift from onshore to offshore, 65 of 120 actual temperature differences were positive, 45 were negative and 12 were zero.

Table 4 shows the changes produced by TLB passage and by the evening wind shift from onshore to offshore.

Table 4 shows that with the passage of a TLE, an increase in stability occurred in 68 cases, a decrease occurred in 28 and 27 showed no change. With the evening wind shift to offshore, the predominant change was toward increasing stability as shown by the 103 positive changes and only 17 negative or zero changes. The most marked increases in stability usually occurred about $3 \mathrm{~h}$ following this wind shift.

A comparison was made between data recorded on the Cook and Palisades meteorological towers for the 38 TLB occurrences in 1978. Of the 38 occurrences in 1978 , complete data for occurrences at both towers were available for 29. Results of the comparison are shown in Table 5 .

Table 5 shows that except for the hour after the evening wind shift from onshore to offshore, the

Table 4. Average changes in $T_{55}-T_{9}$ with passage and retreat of true lake breeze for the Cook meteorological tower*

\begin{tabular}{lcccr}
\hline Sign of change & \multicolumn{2}{c}{ With passage } & \multicolumn{2}{c}{ With evening windshift } \\
\hline & Cases & $\mathrm{C}$ & Cases & $\mathrm{C}$ \\
Negative & 28 & -0.4 & 12 & -0.3 \\
Positive & 68 & +0.4 & 103 & +0.6 \\
Zero & 27 & 0 & 5 & 0 \\
\hline
\end{tabular}

- Differences in the total number of cases in the two categories are caused by missing data. 
Table 5. Comparison of average vertical temperature differences for the Palisades and Cook meteorological towers for 29 true lake breeze occurrences in 1978

\begin{tabular}{|c|c|c|c|c|c|c|c|c|c|c|}
\hline \multirow[t]{2}{*}{$\begin{array}{l}\text { Sign of } \\
\text { change }\end{array}$} & \multirow{2}{*}{$\begin{array}{r}\text { Hour } \\
\text { prior } \\
\text { Cases }\end{array}$} & \multirow{2}{*}{\multicolumn{2}{|c|}{$\begin{array}{r}\text { With } \\
\text { passag } \\
{ }^{\circ} \mathrm{C} \text { Cases }\end{array}$}} & \multicolumn{3}{|c|}{$\begin{array}{l}\text { During } \\
\text { enshore wind }\end{array}$} & \multicolumn{2}{|c|}{$\begin{array}{c}\text { With } \\
\text { retreat }\end{array}$} & \multicolumn{2}{|c|}{$\begin{array}{l}\text { Hour } \\
\text { after }\end{array}$} \\
\hline & & & & ${ }^{\circ} \mathrm{C}$ & Cases & ${ }^{\circ} \mathrm{C}$ & Cases & ${ }^{\circ} \mathrm{C}$ & Cases & ${ }^{\circ} \mathrm{C}$ \\
\hline \multicolumn{11}{|c|}{ Cook } \\
\hline Negative & 29 & -0.8 & 9 & -0.3 & 29 & -0.8 & 6 & -0.4 & 18 & -0.4 \\
\hline $\begin{array}{l}\text { Positive } \\
\text { Zero }\end{array}$ & & & $\begin{array}{r}16 \\
4\end{array}$ & 0.4 & & & 23 & 0.4 & $\begin{array}{l}7 \\
4\end{array}$ & 0.5 \\
\hline \multicolumn{11}{|c|}{ Palisades meteorological tower $\left(T_{60}-T_{10}\right)$} \\
\hline Negative & 27 & -0.8 & 10 & -0.6 & 28 & -0.7 & 1 & -0.4 & 7 & -0.5 \\
\hline Positive & 2 & 1.9 & 14 & 0.2 & 1 & 0.3 & 25 & 0.5 & 19 & 0.8 \\
\hline
\end{tabular}

effects of TLB occurrences on vertical temperature differences at the two locations are similar and generally agree with the results shown in Tables 3 and 4 . The discrepancies for the hour after the evening wind shift are mainly due to the more gradual meteorological changes taking place then as contrasted to the larger and more rapid changes which occur as the TLB moves inland or if it is caused to retreat lakeward by a strong enough offshore gradient wind.

Having an effect on the results described above is the fact that both $60 \mathrm{~m}$ towers are about $0.8 \mathrm{~km}$ inland and their bases are about $40 \mathrm{~m}$ above lake level. Temperature as well as other variables measured on both towers are influenced by internal boundary layers during onshore winds. An internal boundary layer for onshore winds is air near the surface that begins to lose the characteristics of thermal stability and turbulence relatable to its trajectory over water when it crosses the shoreline and begins taking on those characteristics relatable to the land surface. Measurements made by Raynor et al. (1979) show that this layer of air increases in depth with distance inland in a complex way determined by wind speed, surface roughness and horizontal and vertical temperature differences.

The data available in the present study lacked the horizontal and vertical resolution necessary for a determination of boundary layer characteristics. It is likely, however, that in some TLB cases its formation could have caused the vertical temperature differences measured on the towers to be more representative of conditions between the towers and the lake than of conditions over the lake itself.

\section{CONCLUSIONS}

An average of 31 true lake breezes occurred along the eastern shoreline of Lake Michigan between
March and November. The fact that July and August usually had the most frequent occurrences was supported by their also having, on the average, the highest maximum temperatures, the least daytime cloudiness and the lowest wind speeds. Nearly every second TLB moved inland as far as $19 \mathrm{~km}$ station, but many retreated lakeward after having reached some distance inland. This was usually due to an increase in offshore wind speed and/or an increase in cloudiness. Vertical temperature differences recorded on meteorological towers near the shoreline show slight thermal stability for the hour prior to TLB passage, an increase in stability with passage, instability during onshore winds and an increase in stability accompanying an evening wind shift from onshore and offshore.

\section{REFERENCES}

Keen C. S., Lyons W. A. and Schuh J. A. (1979) Air pollution transport studies in a coastal zone using kinematic diagnostic analysis. J. appl. Met. 18, 606-615.

Keen C. S. and Lyons W. A. (1978) Lake/land breeze circulations on the western shore of Lake Michigan. $J$. appl. Met. 17, 1843-1855.

Moroz W. J. (1967) A lake breeze on the eastern shore of Lake Michigan: observations and model. J. Atmos. Sci. 24, 337-355.

Raynor G. S., Sethuraman S. and Brown R. M. (1979) Formation and characteristics of coastal internal boundary layers during onshore flows. Boundary-Layer Met. 16, 487-514.

Ryznar E., Baker D. G. and Moses H. (1976) Coastal meteorological networks to determine effects of nuclear plant cooling systems. Bull. Am. met. Soc. 57, 1441-1446.

Weber M. R. (1978) Average diurnal wind variation in southwestern Lower Michigan. J. appl. Met. 17, 11821189.

Wexler R. (1946) Theory and observations of land and sea breezes. Bull. Am. met. Soc. 27, 272-287. 